\title{
Private International Law
}

\section{'Proper jurisdiction' and the Pakistan National Shipping case by Olusoji Elias}

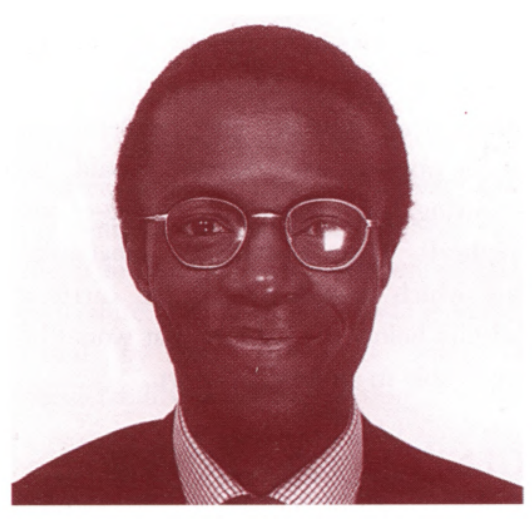

Contemporary transnational litigation of any real consequence for the prospects of its broader framework will not likely exclude the matter of 'propriety' as is defined and identified in the objectively ascertained considerations that will invariably serve the forum's determination of a question arising, be it jurisdictional or substantive.

The matter of propriety is hardly of passing significance in the context of jurisdiction (or procedure) wherein the typifying flexibility-derived factors are pervasive (see, é.g., the judgment of Brandon LJ in The El Amria [1981] 2 Lloyd's Rep 119 at p. 123). These include the discretionary nature of the exercise of the forum's jurisdictional competence, a plaintiff's onus as to proof, and the relevance of all the circumstances of a case: for instance, the location of the evidence; the common ground between the English and the relevant foreign court; the parties' respective jurisdictional connexions; the legitimacy of their quest for a given trial forum; prejudice to the plaintiff by suing in a foreign court. All these have time and again been applied in the English forum. These must, however, be distinguishable from similar, longer-standing features in resolving issues relating to the merits of a particular case. The latter are not the subject of this paper.

This article aims to demonstrate that identifiable analogues, of propriety between jurisdiction/acquisition or declension and the law applicable to the merits, have much to commend them as indicators of the developments anticipated in the broader field of private international legal process.

It is additionally important to emphasise the distinction between jurisdiction and choice-of-law, especially where the facts in issue are not necessarily wholly identifiable with the one jurisdiction. To be clear, the former refers to an agreed forum, the latter to an agreed governing law.

If, indeed 'the next frontier will be international conventions on procedure' (William Tetley QC, International Conflict of Laws: Common, Civil and Maritime, 1994, p. 868), and with it a pending global jurisdiction and judgments convention (see generally, e.g., Charles Platto and William G Horton (ed) Enforcement of Foreign Judgments Worldwide, 2nd edn, 1993), then it is worthwhile to deliberate the issues arising from the wider context of 'proper jurisdiction' which has made its way into accepted parlance.

The primary focus of the present commentary was recently amplified in the ruling of Lord Justice Phillips in the Pakistan National Shipping case (Baghlaf al Safer Factory Co BR for Industry Ltd v Pakistan National Shipping Company; Pakistan National Shipping Corporation (1997) The Times, 17 December 1997, CA. The decision lends itself to the present purpose because it consisted of an authoritative interpretation of the foremost decisions in point (which include The El Amria (cited above), The Hollandia [1983] AC 565 (per Lord Diplock), The Benarty [1985] 1 QB 325 (per Ackner LJ), The Spiliada [1987] 1 AC 460 (per Lord Goff) and, more recently, The Pioneer Container [1984] 2 AC (per Lord Goff)), as well as a thorough-going description of the objective test by which forum jurisdiction is to be exercised in competing forum cases. Consequently, it emphasises those policy considerations which, because they invite the subscription of interested national legal systems' fora, will conduct the globalisation of civil justice - and they are realised in the terms of propriety.

\section{THE FACTS AND RULING}

The facts of the case were these. A carriage of goods by sea contract, evidenced by bills of lading, contained a choice-of-forum clause in favour of the carricrs' (the applicant/defendants in the present appeal) place of business in Pakistan or, at their option, of the forum of the place of final discharge of the goods (Damman, Saudi Arabia). A breach of the contract arose from partial damage to the goods in transit. According to the ruling, the value of the damage - at $£ 20,000$ - was minimal.

Contrary to the clause, the cargo owners (the respondent/plaintiffs) sued for damages in the English commercial courts, claiming the existence of an enabling verbal agreement (at first instance as well as in the appeal, it was held that no agreement had been proved by best evidence on the point), and that the defendants' acts, i.e. acceptance of process, of a time bar extension application and of the arrestability of their sister ship in the event of their not responding - meant that they were estopped from refuting the jurisdictional competence of the English forum. Neither the initiation of proceedings in the competing forum (Pakistan, in the form of a protective writ to show awareness of the running of a time bar; nor in Saudi Arabia for that matter), nor the English forum declining jurisdiction, had featured on the plaintiffs' agenda.

The defendants applied by summons for a stay of the English proceedings; this was granted, as they had vigorously resisted the jurisdiction with the same consistency as they had required clarification from the cargo owners as to the latter's intentions in having begun proceedings there in the first place. Forum or Pakistani law respectively applied a one-year time bar.

1t was held that due service of an English writ did not prevent the forum from independently declining jurisdiction, as it was inherently empowered to do, in favour of an alternative competent forum better suited 
to the trial, to the parties' legitimate interests and to the ends of justice, especially in view of a valid jurisdiction clause. These findings were unexceptional in that they represented fairly settled law on staying actions. But they paved the way for the clarification of the issue of the discretionary bias for the grant of a stay, with the problem expressed by Phillips LJ in the following way:

'Where a claim has become time barred in what would otherwise be the appropriate or agreed jurisdiction in which it should be tried, does this militate in favour of granting a stay of the English proceedings, or against granting a stay, or is it a neutral factor? This is a question which the courts had considered on a number of occasions. There is, in my judgment, no binding decision on the point and different judges have expressed different views'.

The ruling, that a stay would be granted on condition that the defendant/appellants agreed to waive the time bar in Pakistan, was the outcome of relating the present facts to recent decisions in point (referred to above), where the constant denominator was the rcasonableness of the plaintiffs' having chosen to litigate in England, rather than in the contractual forum.

\section{THE CASE LAW}

In Citi-March Ltd v Neptune Orient Lines [1997] 1 Lloyd's Rep 72, an English stay was refused because the plaintiff/respondents had been reasonably motivated to reduce their costs by having sued in England, because the result of doing so was to have saved them from the time bar in the agreed Singaporean forum. In The MC Pearl [1997] Lloyd's Rep 556, the time bar issue was isolated from whether English proceedings should be allowed in default of the agreed South Korean proceedings, because there would have been a reasonable explanation for not having begun timeously in the latter forum. In The Spiliada (at p. 483), Lord Goff made clear that if a plaintiff reasonably began English proceedings and thus allowed a relevant forum's time bar to expire, the proceedings would be stayed only if the defendant agreed to waive an otherwise applicable time bar which ran in the foreign forum.

This view was approved in the Pakistan National Shipping case, with the proviso that reasonableness be objectively ascertained on the basis of all the facts surrounding the plaintiffs' conduct, so that there was no unreasonableness in having sued in England: the applicable amended Hague-Visby Rule, art. IV, r. 5, laid down a larger limit on the carriers' (defendants') liability than did the unamended Hague Rule which would apply in Pakistan - the former rule would not be adverse to the English claim. Moreover, art. III, rule 8 of the former rules nullified any different liabilitylimiting clauses, so that the latter rule, to be applied in Pakistan, was void in the eyes of the English forum.

Indeed, it was to the defendants' good that they agreed at the hearing not to take advantage of the Pakistani limit, because to have done otherwise would have militated against the stay for which they applied. In The Hollandia, it was held that:

[A] choice of forum clause which selects as the exclusive forum for the resolution of disputes a court which will not apply the Hague-Visby Rules, even after such clause has come into operation, does not necessarily always have the effect of lessening the liability of the carrier in a way that attracts the application of article III, paragraph 8' (at p. 574-575).

The present ruling consolidated and amplified the case law by its emphasis on the policy justification for the application of time bars, i.e. the prevention of stale claims (thus, parallel suit in Pakistan would, had it been commenced, have been a pointless technicality, especially since the amount of money involved was negligible in comparison with the parties' costs in Pakistan). The decision also turned on the purpose of the valid jurisdiction clause, to protect the defendant/appellants from being sued in a forum which would disentitle them to a realistic limit (such as was provided for in the amended rule applicable in England) on their liability.

Furthermore, Phillips LJ's application of the Pakistani forum clause was consonant with Brandon LJ's dicta in The El Amria, cited with approval in the Pakistan National Shipping case decision, that:

'for an English Court to investigate [the procedural advantages and disadvantages of rival jurisdictions] and pronounce $a$ judgment on it is not consistent with the mutual respect with which the Courts of friendly states, each of which has a well developed system for the administration of justice, owe, or should owe, to each other' (at p.126)
It is clear that the co-incidents of jurisdiction and choice-of-law simultaneously illustrate the issue of propriety, as a conflicts term of art, and afford a set of principles for the wider purpose of evolving a corpus of jurisdictional rules that are potentially even more compatible with the operation of similar rules in other fora. This would be borne out in the present case by considering whether the exclusive (or most appropriate) forum would, in resolving the merits (via choice-of-law method), apply a domestic substantive law which would reduce the carriers' liability below the liability that would be applicable in an English court.

\section{GENERAL PROCEDURE}

It is useful, at least, to recognise the confluence of similar rationales in other aspects of forum acquisition or exercise of jurisdiction, e.g. in relation to the operation of the doctrine of forum non conveniens when it applies (e.g. as in $R e$ Harrods (Buenos Aires) L'td [1992] Ch 72, Dillon LJ, especially at p. 94) and to antisuit injunctions (e.g. First National Bank of Boston v Union Bank of Switzerland [1990] 1 Lloyd's Rep 32). See also the present writer's comment on Pearce v Ove Arup Partnership Ltd \& Ors in (1997) 9 AJICL $673-676$, on the decline of the role of forum non conveniens in Brussels Convention cases), of lis alibi pendens (see, e.g., the recent decision in Sarrio $S A V$ Kuwait Investment Authority, The Times, 17 November 1997, concerning the staying of actions under art. 22 of the Brussels Convention - the Court of Appeal stayed the English proceedings in favour of Spanish courts, essentially to facilitate the streamlining regional arrangements under the applied convention)

Generally speaking, proper jurisdiction, accordingly described, is consequently concerned with the tenets which will presently be distinguished. It is also necessary to observe that the no less procedural matter of the recognition and enforcement of judgments would appear to require some differentiation in these respects, whether it be founded in principles of the defendant's obligation under the foreign judgment, or the principle of reciprocity between fora. The differentiation is required because what is involved in original jurisdiction cases does not include the question of res judicata, which features in recognition 
and enforcement jurisdiction. Consequently it would be too elastic to seek to apply the same tenets to the latter (see, e.g., 'Proper Law of a (Restitutionary) Remedy?' Denning Law Journal).

In so far as judgment recognition and enforcement depends on jurisdiction being had, it makes sense that the latter be clearly resolved and reckoned with, in order to ensure similar resolution of the former, mindful none the less that judgments are arguably more indicative of the true extent of globalisation of civil procedure. The judgments issue is in fact eased by the fact that want of predictability of the jurisdiction in which a judgment, properly so-called (and this would include interim orders), is to be recognised and enforced is not necessarily a restrictive factor. The pre-requirements for the judicial exercise concerned have (subject typically to public policy and forum discretion) generally been accepted in uniform terms in most jurisdictions. These judgment requirements, in their application in standard recognition and enforcement cases, are in reality, but the conceptual analogues of possible, rather than actual (or lis alibi pendens), parallel forum litigation in original jurisdiction cases.

\section{OBJECTIVE \\ CONSIDERATIONS}

Thus, from the forum's point of view and indeed from the perspective of parties in rcasonable preparation for trial in transnational litigation in general - the following objective considerations are paramount in that they even things out between the jurisdictions concerned:

- flexibility as to the content and the applicability of the relevant, particular forum law, as well as the bearing it is to have on the issues;

- party autonomy, beyond the validation of their choice-of-forum clauses and the submission of the given dispute to the one forum, e.g., in relation to the right to waive or assert procedural rights which are exercisable in the other jurisdiction(s);

- objectivity, rather than subjectivity; e.g., on the matter of reasonableness, in determining the jurisdiction with which the parties and their dispute are most closely connected;

- uniformity, predictability and consistency of result, regardless of the forum in which litigation is commenced, to be differentiated from the content; also the result of applying the choice-of-law rule of the particular jurisdiction, i.e. procedural fairness in the case in point, the likelihood of delay and (or) fair trial if litigation took place in Pakistan;

- mandatory forum rules and forum public policy, as may be applicable to these issues (mostly in connection with the recognition and enforcement of judgments, where this arises);

- procedural trade-offs between entitlements accruing from forum rules and from the rules of the other jurisdiction;

\section{- comity.}

As much is sufficiently clear from the cases referred to above and, as was said at the outset, these considerations constitute the standard parameters in the approach of most systems to the questions of form considered here. The considerations identified above cumulatively make for efficient dispute resolution, the prevention of costly litigation, consistent judgments, and appropriate protection for either party; all over-arching points to which every forum relates.

\section{SYSTEM DIFFERENCES}

However, there are also the inevitable system-differentiating inferences that must simultaneously be drawn as to the inseparability of the locality (and the interest) of the forum from any meaningful assessment of the quality of its jurisdictional competence. Forum interest will continue to be less casily resolved in optimising the harmonisation of the procedures and other jurisdictional rules and principles of different fora. The harmonising process, as has been furthered by the various regional arrangements relating to these matters (see, e.g., Transnational Tort Litigation: Jursidictional Principles (1996), C McLachlan and the Hon Peter Nygh ed, Ch 2-4, and the ASEAN and the ECOWAS Conventions), more often than not appears convincingly to represent the underpinnings of an operable global jurisdiction and judgments convention. The resolution of these disparities is not necessarily assisted by a sufficiently uniform characterisation of the causes to which the jurisdictional rules are to apply; it is a bonus that these matters are undergoing the required refinements.
For example, in Klcinwort Benson Ltd $v$ Glasgow City Council, The Times, 31 October 1997 (Lord Goff) - an action for English judgment for the recovery of money paid - the House of Lords decided in favour of a separate characterisation of restitution or enrichment actions (from contract claims) away from the scheme of art. 5(1) of the Brussels Convention.

\section{CONCLUSION}

In English courts, competing jurisdiction cases which fall outside the scope of the Brussels Convention, and in US and other common law courts, in which the doctrine of for um non conveniens continues properly to apply (be it as a result of there being a lis alibi pendens, or of the mere possibility (cf. Connelly $v$ RTZ Corporation plc [1997] 3 WLR 373, $\mathrm{HL}$ ), or even the imminence of suit elsewhere on the same facts, as in the Pakistan National Shipping case), will illustrate the contemporary limits to harmonisation - if that is in fact what they are - and the utility of regional and bilateral jurisdiction agreements. The forum's retention of discretion in acquiring or declining jurisdiction in such cases still depends on the normal lex fori rules of the forum in question. But this is hardly a distortionary bugbear if, for cxample, its objectivism is compared with the particular problem of legal systems which ostensibly are not part of the deliberations on the globalisation of civil procedure (cf. Platto and Horton).

The attractions of an evolving global jurisdiction and judgments protocol have generated the enthusiasm which produced the foregoing comment which, self-evidently is, in its terms, not concerned with the incidence of the type of claims involved being settled out of court, as was noted in the ruling. It is no surprise that even autonomous settlements, arbitration and other alternative dispute resolution mechanisms, will be found to depend to a greater or lesser extent - on the propriety of any applicable legal considerations.

\section{Olusoji Elias \\ University of Buckingham}

The author is a member of the IBA International Litigation Committee 